\title{
The Architecture of Synagogues in the Territory of the Don River and Caucasus Areas in the Late 19 and Early 20 Centuries
}

\author{
Grigoryi Shapiro ${ }^{1,2, a}$ Anna Ivanova-Iliicheva ${ }^{1, *}$ Aleksandr Buchka ${ }^{1, b}$ \\ ${ }^{1}$ Department of History of Architecture, Art and Architectural Renovation, Southern Federal University, Rostov- \\ on-Don, Russia \\ ${ }^{2}$ Architect «Al Expert» LLC, Rostov-on-Don, Russia \\ ${ }^{a}$ Email: shapirogr@mail.ru \\ ${ }^{b}$ Email: abuchka@mail.ru \\ *Corresponding author. Email: ami0202@yandex.ru
}

\begin{abstract}
The article is devoted to a comprehensive study of the architecture of synagogues in the southern region of the Russian Empire (the Don and Caucasus region) during the second half of the 19 to early 20 centuries in the context of all-European and all-Russian trends of Jewish religious architecture. The principles of synagogues' siting in the structure of region settlements and their role in cultural and historical landscape are shown in the article. As well as the article presents the typology of spatial planning and constructive concepts, the genesis of artistic image and main stylistic trends.
\end{abstract}

Keywords: Architecture of synagogues, Semantics, Artistic image.

\section{INTRODUCTION}

The synagogues of the Don region, Caucasus and Transcaucasus territories where areas of dense residence of several Jewish ethnic subgroups (Ashkenazi, Georgian and Gorsky) were formed at the turn of the centuries due to the historical circumstances are studied superficially nowadays and outside the context of all-Russian and allEuropean trends of synagogue architecture. Many monuments, adapted during the Soviet period for other functions, are not introduced into the context of the architectural heritage of the Jews and several synagogue buildings are not survived to this day and have never been studied in the context of the regional architecture of synagogues.

Architectural classification and identification of the planning typology, symbolic complex and evolutionary process of synagogue buildings style formation in the context of European synagogue architecture will fill the gap in understanding the formation of a holistic view of the historical and architectural process in the cities of the region.
The territorial boundaries of the study cover urban and rural settlements of the Don and Caucasus region: Rostov-on-Don, Taganrog, Tbilisi, Kutaisi, Oni, Kulashi, Akhaltsikhe, Vani, Baku, Grozny, Derbent, Cuba, Kislovodsk, Pyatigorsk, Makhachkala and Buynaksk. Such variety of territorial boundaries is due to the uniqueness of the region which lies in the neighborhood of Jewish communities of several ethnic subgroups: Ashkenazi, Gorsky, Georgian Jews and Karaites who had individual peculiarities in the performance of religious ceremonies and organization of liturgical space (unlike most regions of the Russian Empire where Ashkenazi Jews lived mainly).

\section{FORMATION FACTORS OF THE ARCHITECTURE OF SYNAGOGUES IN THE REGION}

The synagogue architecture in the region was formed in the second half of the 19 century. On the basis of the analysis the main conditions for its formation are identified and systematized: 
- $\quad$ Sacred traditions that define the synagogue as a cultural and religious mandatory center for any area of dense residence and regulate the organization of the liturgical space.

- Non-professional backgrounds: the economic aspects of the communities of the region; socio-political background and ideological aspects. For instance, there are the following factors: the increase in trade of the Jewish population with the capital regions and countries of Central and Eastern Europe, the allocation of groups of Jewish industrialists, artisans, cantonists; changes in the legislative framework in non-Orthodox spiritual architecture, etc.

- Intra-professional trends at all-European, all-Russian and regional levels. Since the middle of the 19 century Jewish communities in the region have actively involved the representatives of various architectural schools in the construction of synagogues. Thus, both city architects and civil engineers (Sovitsky, M. Petrov) and architects of St. Petersburg (Gevirts, Shaposhnikov) were involved in the design of synagogues. It provided a great variety

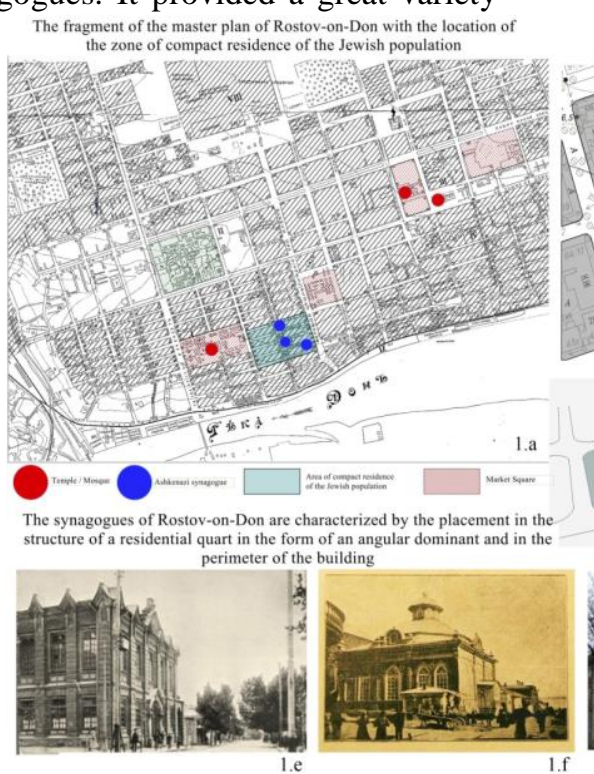

Detail of a sweep along Bauman Streed.

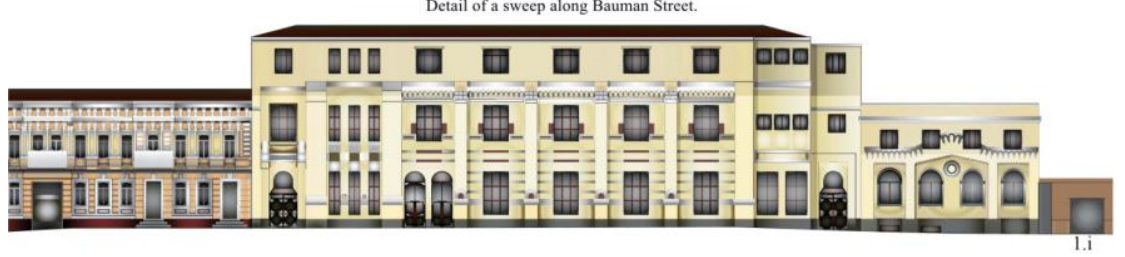

Figure 1 Synagogues in the urban development of Rostov-on-Don. of architectural and artistic solutions of synagogue buildings, the introduction of modern technologies and materials for that time. Typical plans of synagogues were developed in the neoclassical style in the capital for provincial towns which greatly accelerated the process of the synagogue construction but that deprived them of their uniqueness.

\section{THE ROLE OF SYNAGOGUES IN THE STRUCTURE OF REGION SETTLEMENTS}

The analysis of cartographical documents showed that synagogues in the Don region were built in a single area of dense residence, the planning structure of which was similar to that in the central part of the city: an ordered system of streets formed rectangular blocks [1]. The perimeter of the block area of dense residence of the Jews in the Don region was a like ring of adjacent firewall walls of small and medium height buildings with "arches-punctures" leading to the inner part of blocks which had a vernacular peculiarity of construction and low floors ("Figure 1").

The core of the Jewish population in Rostov-on-Don
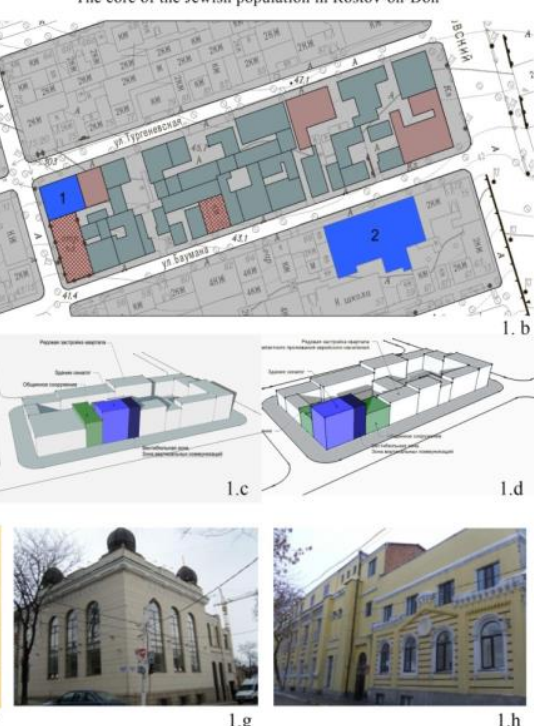

d

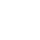


However, the situation in the Caucasus is different: the construction of "Jewish districts"" is random with numerous layers of different times. Synagogue buildings are "unseen" among the buildings range. A new tendency to build a "new" Jewish quarter with a "new" synagogue was peculiar for several large cities of the Caucasus region. In some cases, this was due to the growth of Jewish community or due to the new ethnic group in the city (for example, the old quarter of "Georgian" Jews and the "new" quarter Ashkenazi) ("Figure 2").
The siting of synagogues in the structure of settlements with a dominant Christian population (towns of the Don region, Kutaisi, Tiflis provinces) generally corresponds to the European principles: synagogues are not included in the system of visual links at a city level dominating at the quarter level; narrow visibility and no relation with the natural landscape is peculiar. Dominating at the quarter level, synagogues of the Don region are not included in the system of visual links at the city level and are not the elements of a representative linear ensemble perceived from the left bank of the river Don ("Figure 1"-1.a).

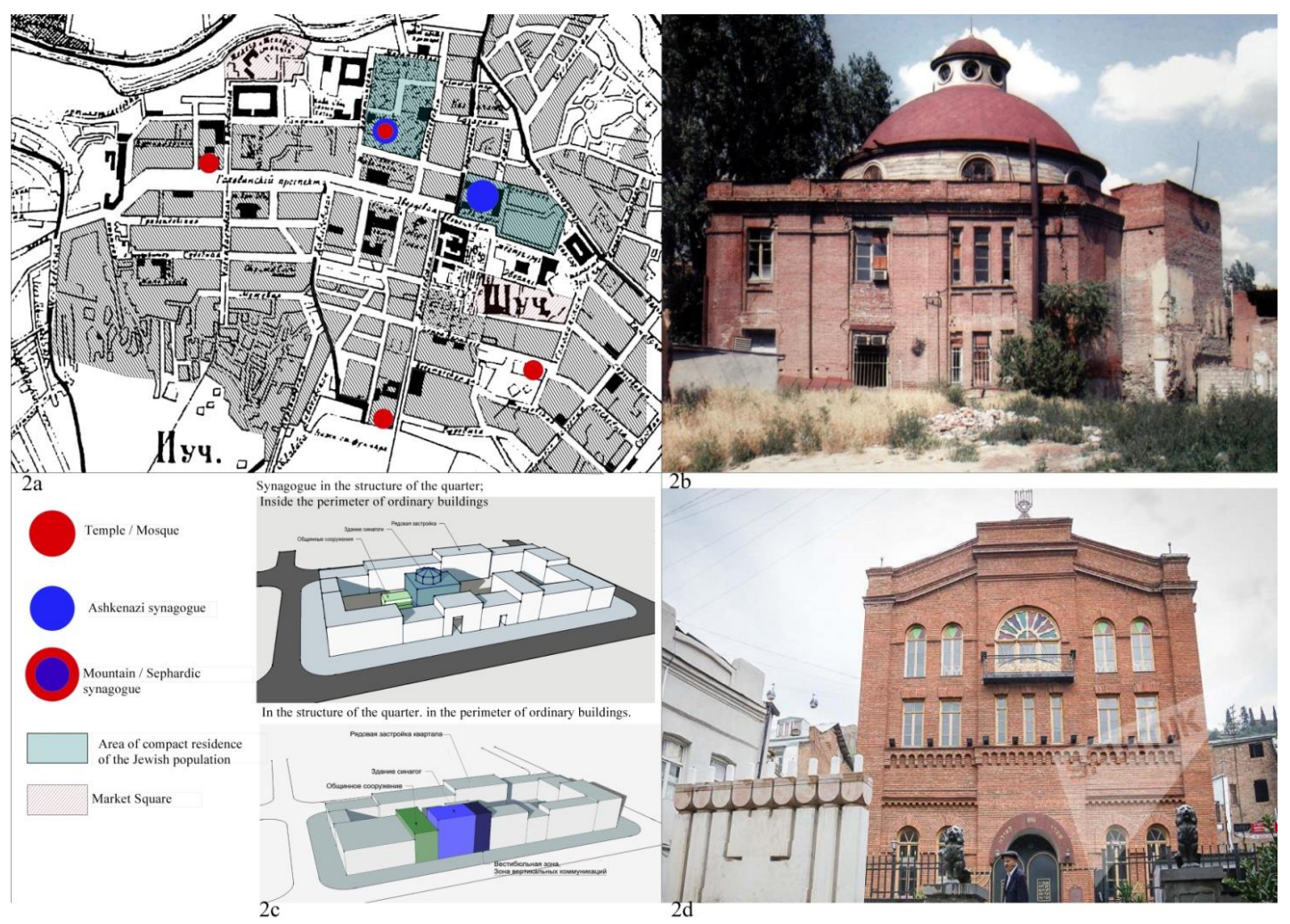

Figure 2 Synagogues in the urban development of Tiflis.

a 2a. Map of the historic center of Tiflis with synagogue locations. 2b. Rotondal synagogue of Tiflis. 2c. Layout of synagogues in the structure of Tiflis quarters. 2d. The Great synagogue in Tiflis.

The dominant location of synagogue buildings (on squares, near large water bodies, in open areas), the equivalence of the synagogue with Muslim mosques in the hierarchy of urban planning, compositional and artistic concepts, the organic visual relationship of synagogue buildings with the natural and anthropogenic landscape is peculiar to synagogues located in settlements with a predominant Muslim population.

The principles of synagogues' siting in the structure of Jewish blocks and streets:
- (1) The synagogue is located in the center of a yard or a block and is not visible from the street. As a rule, it is an independent building, not adjacent to neighboring buildings. A good example is the Jewish church-house located on the territory of Alexander hospital in Rostov-on-Don. Official records [2] allowed to reveal the location of the synagogue in the structure of the general layout of the hospital. Thus, the synagogue was added to the northern courtyard facade from Shahumyan Street with a big setback from the frontage line. $\mathrm{T}$ - shape form of planning structure of the 
hospital didn't allow viewing the synagogue building from the main eastern facade along the Bogatyanovsky slope. The siting of the synagogue caused the shading of the building from the southern facade of the hospital building and the lack of territory in front of the western facade.

- (2) The synagogue is oriented towards the street with its longitudinal side. It was constructed both on the frontage line and with some depth. Thus, the synagogue building is maximally integrated into the quarter building both stylistically and compositionally. This is typical for Jewish blocks in large and medium - sized cities with the so-called "interior" buildings when buildings were constructed closely to each other. The building is perceived only from one facade (north or south). Secondary outbuildings are located in the back of the yard.

This is typical for the synagogue siting in the structure of regular blocks with a restrained ring of ribbon buildings.

There are two typical examples: The Choral Synagogue in Rostov-on-Don and the Jewish Church-house of Nakhichevan.

The area of dense residence of Jewish population of Rostov-on-Don was formed in one of the quarters near the market square and the main shopping streets. This territory of the city was an outskirts of St. Dmitry Rostovsky Fortress and was located on the slope to the river Don which led to the division of rectangular blocks by through shopping streets. A number of wide cross streets such as Bauman Street, Temernitskaya Street, Ulyanovskaya Street formed some kind of a terrace with a single relief connecting blocks against each other and the market square. The main facades of large public buildings face these streets due to the possibility to organize the entrance and a territory in front of it. The ribbon building was mostly continuous with two and four-storey residential buildings adjacent to each other with firewall walls interspersed with public buildings (usually located in the corner site).

The Jewish block was located within the boundaries of Bauman Street, Ulyanovskaya Street, Gazetny lane and Bolshoy Avenue. The building of the main synagogue in its original version was located on the long territory from east to west adjacent to the frontage line by its longitudinal northern facade. The main western facade with a compositionally marked porch was located perpendicular to Bauman Street and led to the narrow yard - court of honor. Thus, the area in front of the main facade which is not visible from Bauman Street was formed.

The urban planning of Nakhichevan had a similar structure: regular block building is located on the slope to the river. A distinctive feature is a low number of floors of the ribbon building and an ordered inner-bloc building. The Nakhichevan church-house is located on the 12th Line on the area with a variation in relief in 1 meter. From the north and south the building was adjacent by firewall walls to the neighboring buildings; the entrance was on the west side.

- (3) The Synagogue faces the street with its western facade where there is the main entrance. In this case, the spatial axis "Lobby - Bimah - Torah ark" is perpendicular to the front line of the quarter. Like the previous type, this one provides the development of a synagogue complex in the depth of a quarter. However, yard becomes more open due to the entrance on the opposite side of the quarter owing to the need to organize the entrance to the longitudinal sides of the building and fire requirements. A free passage front is formed along the southern and northern facades and this allows to organize the lighting of the prayer hall.

In the Russian Empire the Great Choral Synagogue of St. Petersburg and Moscow Choral Synagogue are located similarly.

- (4) The city synagogue in the corner site of the quarter is perceived from two facades. It is a quarter dominant. In some cities the synagogue building is surrounded by a landscape. Such location is revealed in the cities where a place for a synagogue building was laid in advance during the planning process of Jewish quarter. The location is proper for a building with the prayer hall orientation to the East which allows varying the location of functional areas of the synagogue: ladder tie, stairwells to the ladies' room, community rooms, etc.

A good example is The Soldier Synagogue in Rostov-on-Don: a corner site in the Jewish quarter located at the intersection of Gazetny lane and Turgenevskaya Street ("Figure 1"-1.a). It has a height discontinuity in 1.5 meter in the north-south direction which causes the construction of a high ground floor. A community building adjoins the synagogue on its east side in Turgenevskaya Street 
and on the south side - the house of the rabbi. Thus, the location in the structure of the quarter determines the dominant position of the synagogue, a wide visibility catchment area, two-way lighting of the prayer hall and a proper orientation of the axis "Bimah - Torah ark" to the east.

Similarly, the synagogue in Taganrog is located in the quarter building in Petrovskaya Street. It is a grandiose building which is constructed in the Moorish style with a high basement in a corner site with a level terrain. The location provides a wide visibility catchment area and dominance in the composition of the quarter.

- (5) A large city synagogue located on a separate area with a western facade facing the square. The longitudinal facades also remained free from the adjacent buildings. Such arrangement of synagogue in the urban structure became possible during the

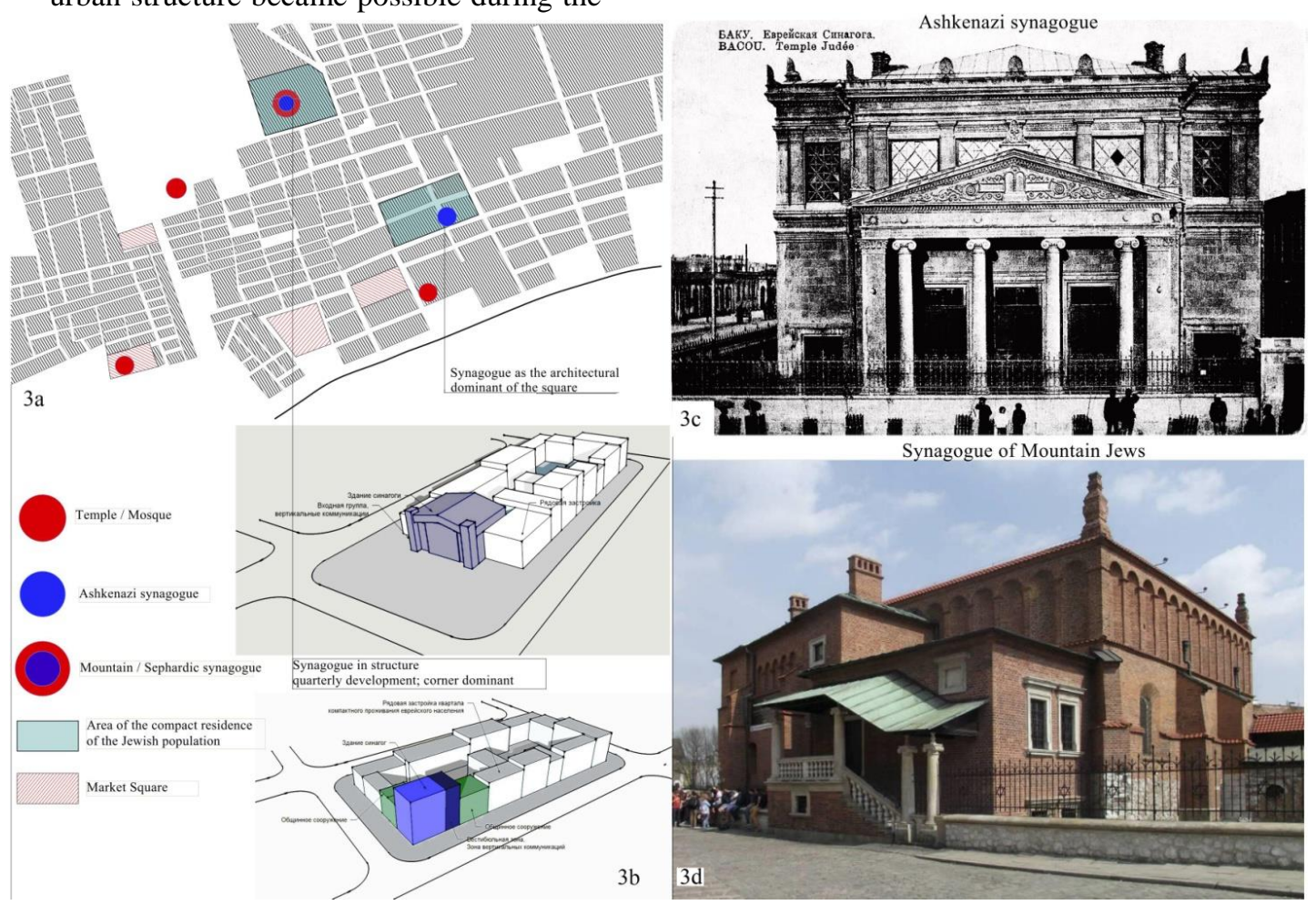

Figure 3 Synagogues in the urban development of Baku.

- (6) Synagogue on the bank of a river. Usually one side faces the waterfront, the other one faces the main street. Sometimes there was a small square in front of the western facade. Due to the close siting to the river or pond there formed a characteristic environment around the synagogue complexes. ("Figure 4") period of Jewish emancipation and progressive Judaism as the area in front of the building is typical for Christian religious buildings and large public buildings (theaters, banks, etc.) with which the synagogues began to "be associated with". As a rule, synagogues were built in the square by rich Ashkenazi communities of industrialists in such large cities as Baku, Ekaterinoslav and Tbilisi in the 10th years of 20 century.

Baku Choral Synagogue is located at the intersection of Nizami and Rashid Behbudov Street ("Figure 3"). Its main western facade faces an open square, the northern longitudinal facade faces Nizami Street and the southern and eastern facades face the intra-quarter driveways. The neoclassical ensemble of the building has a wide visibility catchment area and forms the space of the square. 
the element of the town silhouette and one of the compositional dominants of the city along with the mosque. The main western facade faces the river, the space around the building is landscaped which provided free passage, illumination and orientation of the prayer hall to the east.

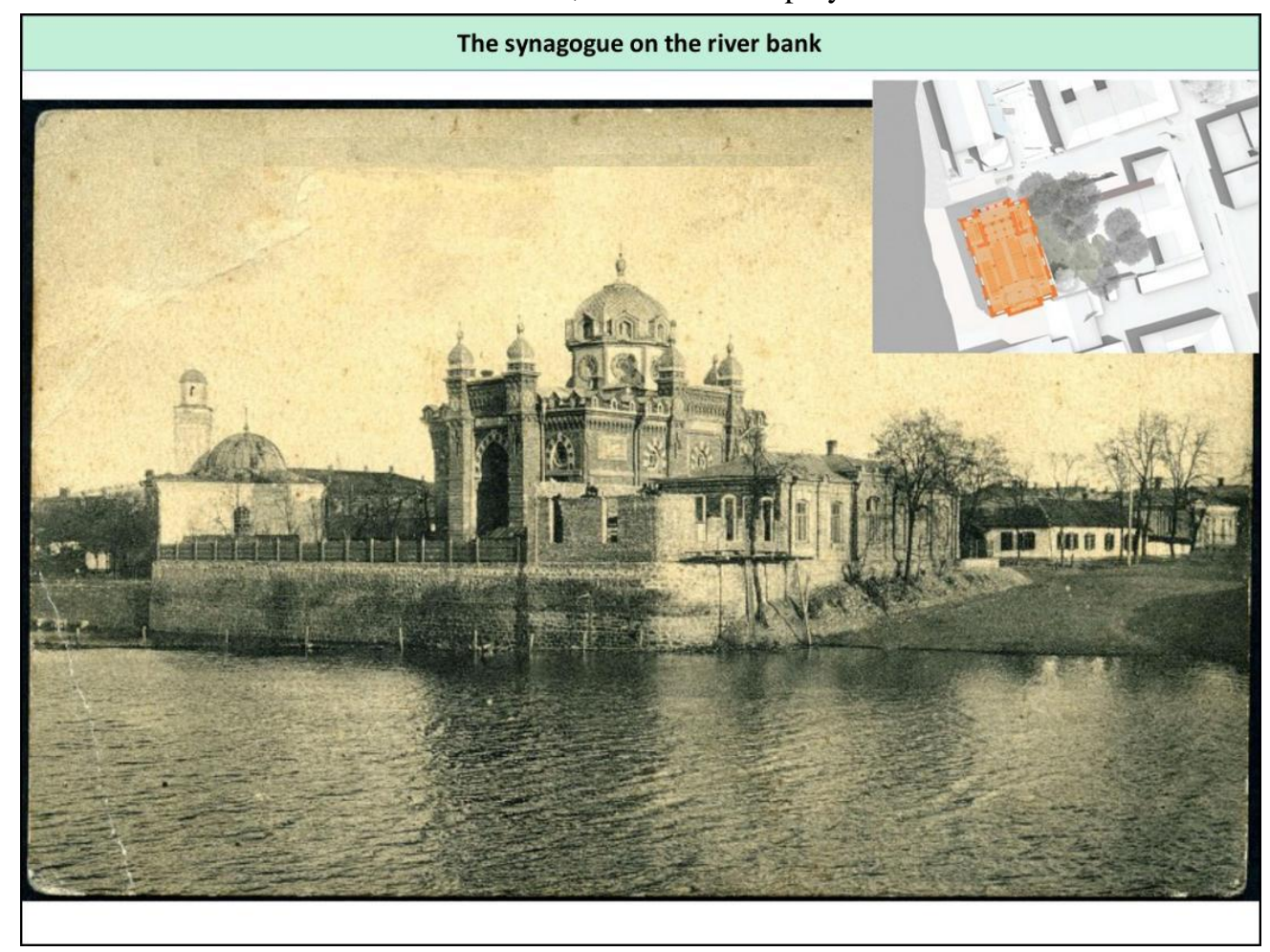

Figure 4 Synagogue in Grozny.

\section{THE SPACE-PLANNING CONCEPT OF THE SYNAGOGUES IN THE REGION}

The internal space for synagogue buildings in contrast to the external form is supreme and sacred. It has its historical canons and semantic significance. The internal space of the synagogue is determined by correlation of the main functional areas: the church hall; ladies' room (ezrat-nashim) as a separate zone or in the structure of the prayer hall; lobby (polish); secondary rooms: mikvah, matzah bakery, alms-house and yeshivah.

The organization of the prayer hall space is filled with symbolic meanings. There are three main spatial parts - two main objects: Bimah and Torah ark, as well as the decision to overlap the hall and all that became fundamental elements in the construction of the prayer space. The following types of interposition of Bima and Torah ark are identified in the synagogues of the region: the centric location of Bimah in the structure of the prayer hall; Bimah location is off-center to the side of Torah ark; the formation of a single altar space
(Mizrahi) which is peculiar to reformistic synagogues.

There is a list of identified types of spatial planning concepts of synagogues:

- "Pillarless type" is characterized by a onenave long square prayer hall with external main walls without pillars. The following variants of ladies' room lay out in the pillarless synagogues of the region are determined: one room is along the western wall, two ones are along the longitudinal northern and southern walls and a Ushaped room.

Mostly, access to the room was carried out through stairs separated from the entrance. For example, the staircase in The Soldier Synagogue in Rostov-on-Don leading to the ladies' room was adjacent to the southern wall of the prayer hall and was connected with the lobby area. But also there are synagogues with two flanking stairwells with direct access to the outside.

The construction of the prayer hall ceiling varied depending on the region and the resources of the community: stone semi-cylindrical arches with vaulting cells are typical for Georgian synagogues 
(Akhaltsikhe, Vani and Kutaisi), wooden (false) arches are in the synagogue in Taganrog, flat wooden ceilings in Guba and reinforced concrete slabs in Rostov-on-Don.

- "Four piers type". We shall consider the synagogue in Oni in Georgia from the point of view of the planning structure. The entrance to the square prayer hall is from the porch and there is no lobby area. Four stone counterforts and external stone walls form the basis of the structural system of the building. The planning structure has three naves; Bimah is off-centre to Torah ark. The central nave is overlapped by the system of semicircular arches with spacers on the inner columns. A round drum made of local stone and a copper dome drum is supported at the semicircular arches. The area of the arches supporting is highlighted with a stylized capitals with floral ornament.

The narrower side naves are overlapped by a system of drop arches and vaults supported at the inner columns and external walls. The roof covering of the side naves by galvanized steel roof is supported at wooden beams.

The upper gallery stretches along the western wall and is supported at a number of inner supports and the outer western wall. It is entered via an internal open staircase located directly in the prayer hall.

This synagogue is featured for the organization of the prayer space according to the "Sephardic type": benches for people are located along the axis "Bimah - Torah ark" which is typical for Georgian Jews.

Such planning concept has a synagogue in Grozny. The analysis of archival graphic documents showed that the entrance to the square prayer hall was carried out through the lobby area. The prayer hall has a square plan with four inner pillars that divide it into three naves. The system of semicircular arches served as a support for the dome drum and the frame of the roof. The Ushaped ladies' room was supported by a system of internal supports and external walls. The entrance was through two flanking vestibule stairwells with direct exit to the outside.

- Type of synagogue with a three-nave prayer hall in Basilican style with four staircases. There are separate overlappings of the central and lateral naves.

The construction of synagogues with 4 ladder ties is due to a significant increase in the inner space of synagogues and the arrangement of communal space of small prayer halls and sidelong choirs (in choral synagogues) above the prayer hall. Such synagogues appeared in large provincial towns (Tbilisi, Baku and Rostov-on-Don) where the type of choral synagogues was popular from the middle of the 19 century.

The stairwells are angular: two stairwells with an exit outside or the exit is in the allocated lobby (as, for example, in The Choral Synagogue of Rostov-on-Don) goes to ladies' rooms, and two ones - in small prayer hall or in secondary communal rooms.

The prayer hall is three-nave and is constructed in the Basilican type. Large staircase spans of the prayer hall could be overlapped by three rows of cylindrical vaults supported by columns through longitudinal beams, 9-12 sail vaults supported by columns, pilasters and external walls.

The support of the ladies' rooms was carried out as follows:

- $\quad$ - on the intermediate capitals of the internal columns;

- $\quad$ - on cantilever beams;

- - on racks differentiated from the main structural system of the building.

The planning structure of The Choral Synagogue of Rostov-on-Don is divided along the longitudinal axis "WEST-EAST" into three blocks: the lobby block in the center of the planning axis with flanking blocks of staircases; the block of the prayer hall of the Basilican type with three naves and the upper room with a conch covered with exedra and the block of secondary rooms with flanking eastern facade blocks of staircases.

- $\quad$ Rotunda type of synagogue like a circle put in a square with a circular gallery.

Such planning concept was almost never met on the territory of the Russian Empire. A striking example is the synagogue "Temple" in Lviv ("Figure 5"). 


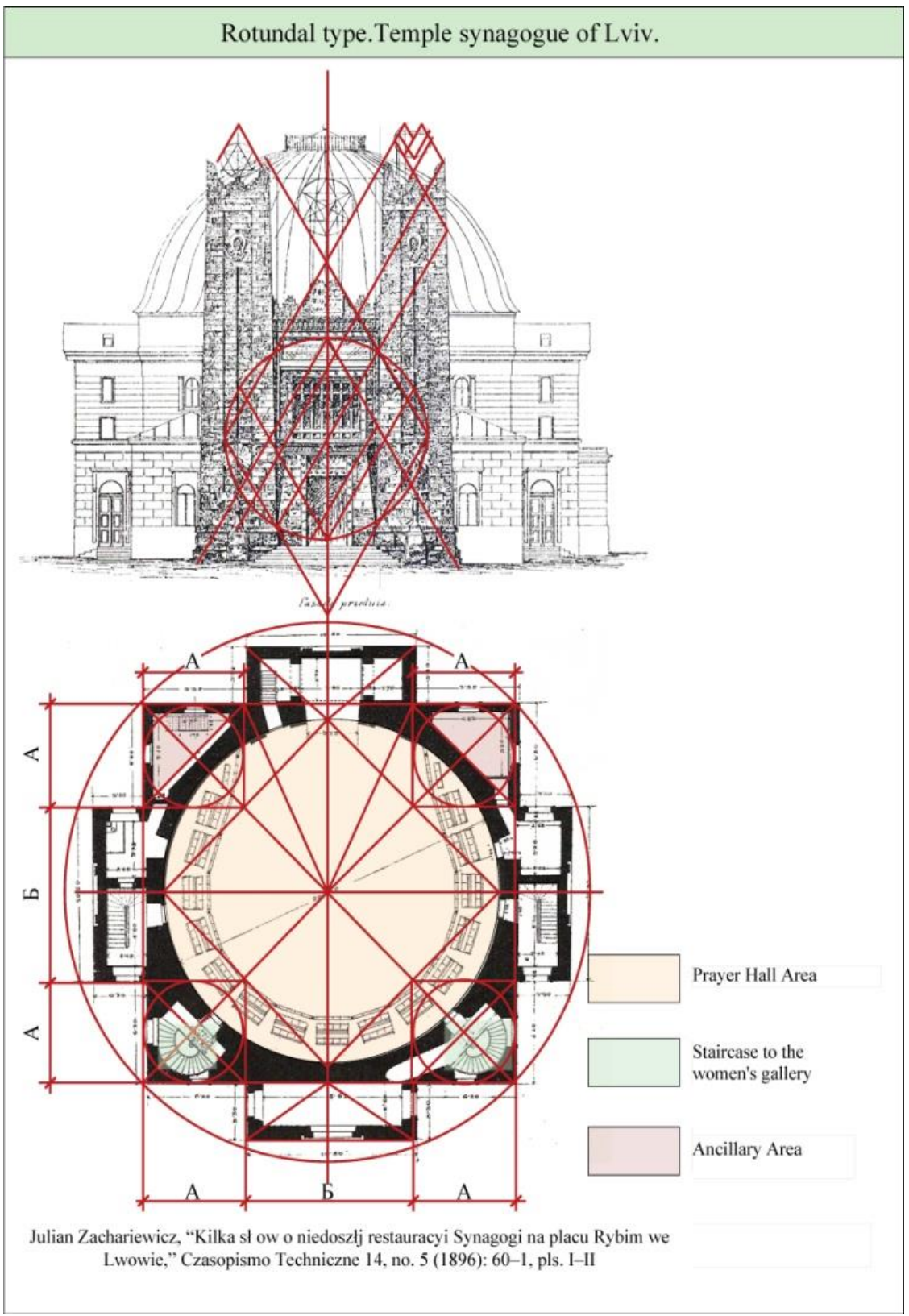

Figure 5 Rotundal type. Temple synagogue in Lviv Facade and plan.

The synagogue of Georgian Jews in Tbilisi in Leselidze Street was built in 1913 ("Figure 6"). A three-part building with a vestibule area, a staircase to the ladies' room and a secondary room is attached to the round prayer hall on the west side. The compositional analysis of the synagogue plan revealed the golden proportion in the ratio of the length of the polish to the length of the western facade. On the eastern and northern sides secondary rooms and stairwells are built. Gallery of the second-tier breaks in the area of Torah ark and is supported by a number of double columns. The walls of the prayer hall rising above the level of the roof serve as a double dome drum. Lighting of the prayer hall is carried out by several round apertures in the upper tier. Thus, the architectural concept of the synagogue is represented like a cylinder in a cube. 


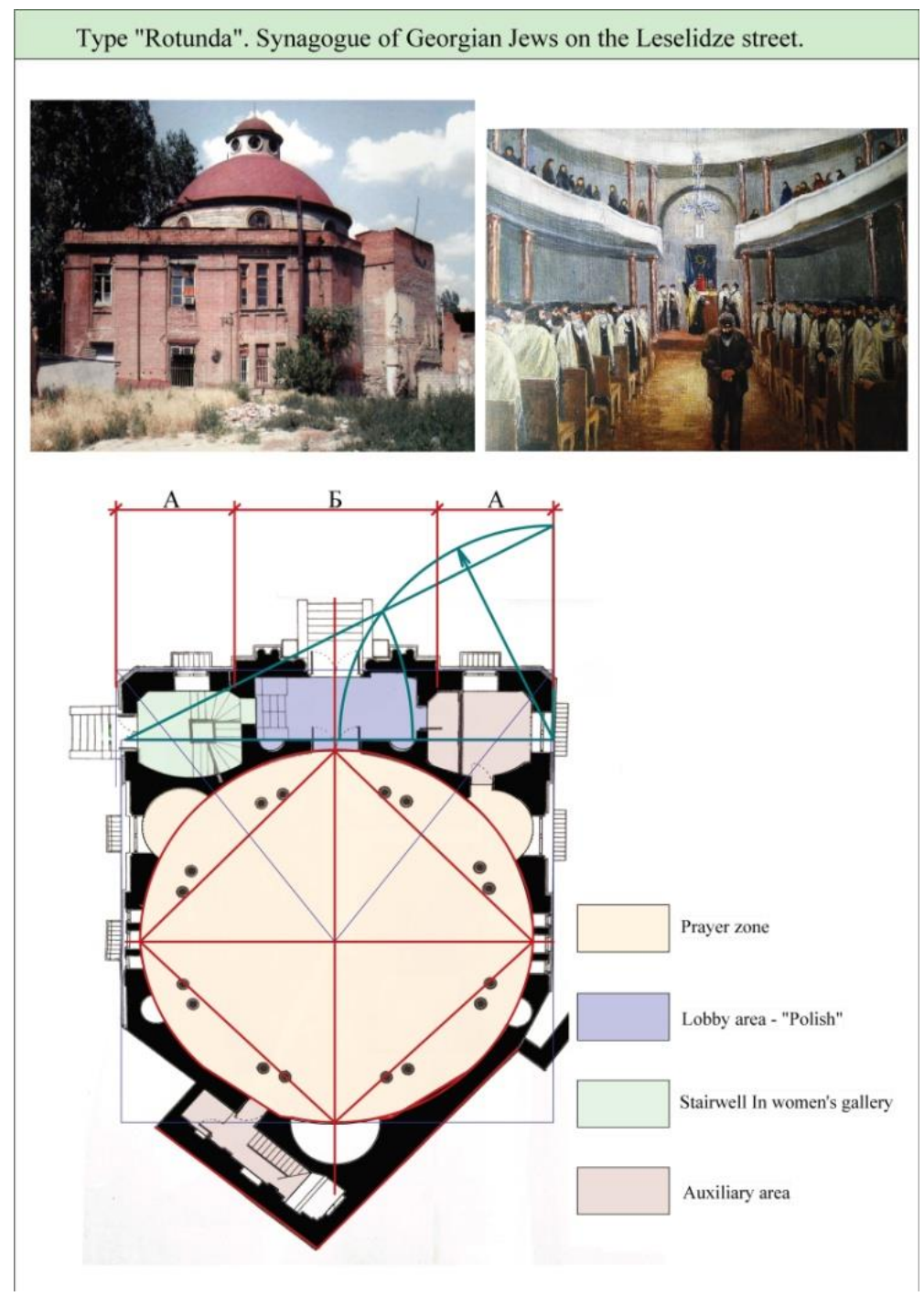

Figure 6 Type "Rotunda". Synagogue of Georgian Jews on the Leselidze street (Facade and plan and interior drawing).

\section{ARTISTIC IMAGE, \\ COMPOSITIONAL AND SPACE CONCEPT OF THE SYNAGOGUES IN THE REGION}

The artistic image of a synagogue acts as a relatively independent architectural formation and as a kind of artistic integrity. According to Y. S. Yankovskaya, "The image is a bridge between the real architectural object and our cognitive ability" [3]. The figurative concept of the synagogues of the region is formed in the relationship between individual and typical. Without denying the individual component (especially in buildings of the 10th years of 20 century) in the architecture of synagogues, the typical part is presented as fundamental. Namely the prototypical principle determined the ideological side of artistic images and strongly serves a political function.

"The image of recognition" as a component of the figurative structure of the architectural object due to religious canons, socio-political conditions, features of historical and cultural development in the synagogue architecture was not formed as a canon. In addition, the recognition of the object as a synagogue unlike other confession was not required and in some cases was avoided. According to a number of circumstances (primarily political, social and economic) the image of a particular synagogue was formed on the basis of certain architectural prototypes that have a capacious semantic saturation.

Semiotic mechanisms of the synagogue architecture are not aimed to reveal the synagogue 
construction (at least for "the inhabitant"). Symbolic compositional elements are introduced to recognize the building as a synagogue that do not affect the general perception of the facilities and do not cause associations connected with Judaism, but serve as a "a code": the two columns flanking the main entrance, round window opening on the eastern facade, towers of staircases flanking the entrance portal, 12 window openings on the longitudinal facades of the prayer hall, double window openings and semicircular niches.

The building of the Choral Synagogue in Baku (now theatre) ("Figure 3"a-c) has a concept of architectural forms of public building: a pompous brick plastered building with neoclassical elements in the exterior. The main western facade has a three-part structure: the central volume with a portal capped by a classic attic on the ionic columns divided by canelures and is flanked by staircases with quadrate towers on both sides. In the triangular tympanum of the attic there is a niche in the form of "David's shield". The cornice of the attic is decorated with modillians. The prayer hall of the Basilican form has a flattened dome. The walls are decorated with rustication and profiled cornices. Window openings of the upper tier are capped by classic cornices and flanked by semi-columns.

The Moscow Choral Synagogue is constructed in this architectural concept: the symmetrical composition including the dominant central part marked with a triangular attic on the Corinthian orders and two lower parts with rusticated surface and rectangular window openings with triangular cornices. A distinctive feature of the synagogue is a high dome over the prayer hall.

Another type is the synagogue built in traditional Byzantine Church architecture concepts of morphogenesis. The synagogue in Grozny ("Figure 4") has two towers in the Moorish style with a dome flanking the entrance portal. The portal was formed by two massive, square three-tier towers. In the second tier they were connected by a majestic arch of oriental silhouette passing into the attic. Thus, the entire entrance portal is perceived from the river side as a single majestic building similar to the composition concept of the neighboring mosque.

There is an octagonal drum dome above the center of the hall turning into an onion-shaped dome. Round openings are arranged with a decorative frame in the faces of the drum. Openings with semicircular completion and archivolts are built into the structure of the dome. The pilaster side of longitudinal facades and corners of the east facade are decorated with domed towers with pinnacles.

The synagogue in Vladikavkaz was built in 1909 and has a similar composition structure but less pompous and decorated ("Figure 7"a-b). Over the hall there is a helmet-shaped elongated dome representing Central Asian trends which are peculiar to a number of synagogues of the Russian Empire in the $10^{\text {th }}$ years of 20 century. The Kharkiv Choral Synagogue has a similar form of the dome peculiar to the Central Asian sanctuaries (architect Y. Gevirtz).

Certainly, the most striking and the first example in Russia is The Choral Synagogue of St. Petersburg. It is a grandiose building (one of the largest synagogues in Europe) which represents a complex with a central volume including a prayer hall of the Basilican type with an apsis on the eastern facade with two side parts representing a complete three-dimensional composition. A magnificent octagonal drum with corner turrets stands over the center. The drum turns into a spherical dome.

Upper lighting through the openings of the drum which is peculiar to the traditional Byzantine temple architecture, significantly changed the perception of the inner space of the prayer hall making it grandeur and sacredness.

In contrast to the pompous synagogues there are the examples of synagogues constructed in the form of an ordinary quarter building. The synagogue of Temir-Khan-Shura (now Buinaksk) is located in the center of the city in Korkmasov Street among residential buildings in a quarter which is mainly inhabited by Jews. The rectangular building consists of three volumes: the main volume includes the prayer hall and two added lobbies. 

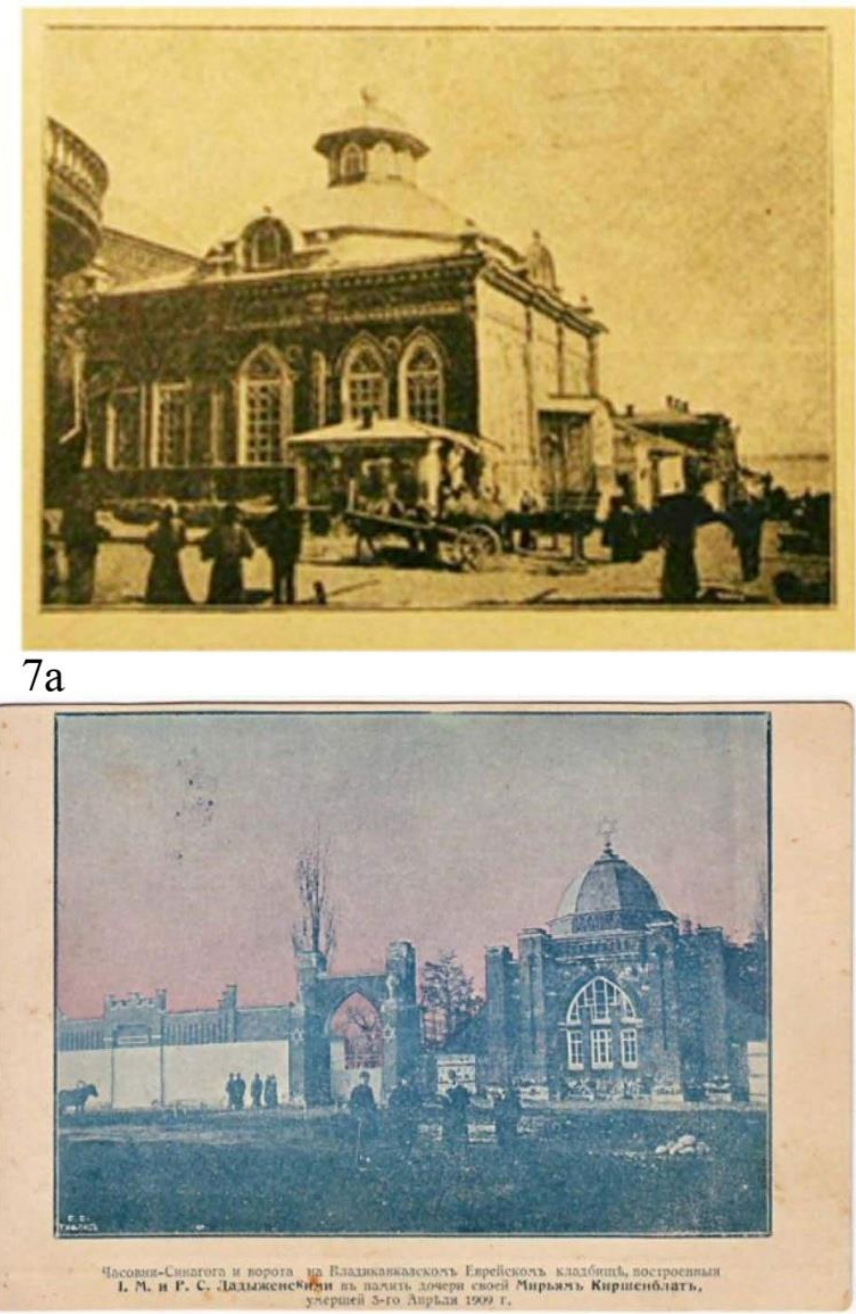

$7 \mathrm{~b}$

Figure 7 Rotundal synagogues.

a 7a. Soldiers' synagogue before reconstruction. 7b. Synagogue of Ashkenazi Jews at the Vladikavkaz cemetery.

The eastern facade with an ascetic composition is divided by 5 pilasters and has 2 large double window openings. The openings are decorated with semicircular arches and profiled archivolts. There is a round opening on the axis of the window in the upper part which is a kind of symbolic marker of the synagogue building. Round openings are also placed above the entrance doors. The northern and southern facades are flanked by two wooden additional buildings.

The western facade is similar to the eastern one in composition, size and decoration, except the fact that it was built of local stone. The facade is divided by 5 pilasters. On the place of the northern opening of the southern window and the southern opening of the northern window there is a blind arch, there are also no upper round openings. A staircase goes from the upper gallery directly outside and is located in the northern part of the facade.

The walls are made of brick. The building almost doesn't have decorative plastics. The western wall is made of brick and local stone. The walls of vestibules are wooden and the basement is brick and plastered. The building is capped by a profiled cornice. The roof is hip, four-pitched and covered with metal. The roof of vestibules is made of cement asbestos coating.

\section{THE STYLISTIC CONCEPTS OF SYNAGOGUES OF THE REGION}

A stylistic diversity in the architecture of the synagogues of Europe and the Russian Empire of 
the second half of the 19 - early 20 centuries was a result of the desire to express national and cultural identity through external architectural forms. It is expressed by a wide stylistic palette from luxuriously decorated romantic historicism of oriental concept to ascetic rational "brick style".

The spread of stylistic trends in the synagogue architecture of the Don and the Caucasus regions is divided into 3 main stages:

- $\quad 1860-1870$ - the architectural image in the eclectic style with a predominance of neoGothic trends and "rundbogenstil";

- $\quad 1880-1890$ - the spread of oriental, mainly neomavritan eclecticism in the synagogue architecture of the region, as a result of the search for the national "Jewish" style;

- 1900-1910 - the architectural image of synagogues in the style of modernism (Oriental style, neoclassical with elements of academic styles, rationalistic style and "brick style").

\subsection{The Neo-Moorish Style}

The spread of Moorish motives in the synagogue architecture of the Don and the Caucasus region was due to the trend of prototyping and borrowing of trends from the capital's architecture. On the basis of the analysis of historiography and authors researches the following sources of influence are marked:

- Decorative ensemble of the Alhambra Palace;

- The Choral Synagogue of St. Petersburg, the project of which is published everywhere;

- Oranienburgerstrasse Synagogue in Berlin (1866) is recommended by the art critic Stasov in 1872 as a model for St. Petersburg Synagogue. The publication of album with drawings by Edward Knoblauch in 1867 made its design and architecture accessible to the general public [4];

- The Mamluk mosque in Cairo which illustrations were widespread in Europe by then [5].

The most characteristic elements of the decorative ensemble of synagogues in the Moorish style:

- openings with horseshoe-shaped, arched or scalloped arches;
- $\quad$ rusticated walls;

- a great many of oriental floral decoration on the walls in the form of bas-reliefs and high reliefs;

- Moorish capitals in columns and pilasters;

- oriental shape of the domes.

The synagogues of the Don region were characterized by the direct borrowing and "cleanness" of neo-moorish style. So, in the original, the Soldier Synagogue in Rostov-on-Don (built in 1870) had a drop window openings, rusticated walls and oriental motives in the decoration of the exterior, aesthetic brick masonry which indicates its secondary purpose in relation to the main Choral Synagogue.

The Choral Synagogue of Rostov-on-Don had similar architectural concepts with the Taganrog synagogue in the style of facades and interior: plastered rusticated walls, horseshoe-shaped semicircular openings in the exterior and interior, decorated pilasters (now lost), the introduction of contrasting tones in the color solution.

The mixing of "pure" neo-moorish stylistic and regional trends is peculiar to synagogues of Yelizavetpol province, especially for Jewish settlement. So, in 80-s, 90-s of the 19 century in Jewish settlement architect Hillel Ben Haim designed a number of synagogues in the typical eclectic style: exterior unplastered brick walls, keeled openings (in the Russian Empire it was a feature of the neo-Russian style), onion-shaped domes and brick decor similar to the surrounding civil architecture (sockets, thrust, niches). [6]

The spread of neo-Moorish style is not typical for synagogues of Georgia. The only exception is the synagogue in Oni ("Figure 8") where oriental motives are synthesized with a characteristic "Racha" decor. Features of plastic facades are determined by a finishing material of the outer walls - sandstone. 


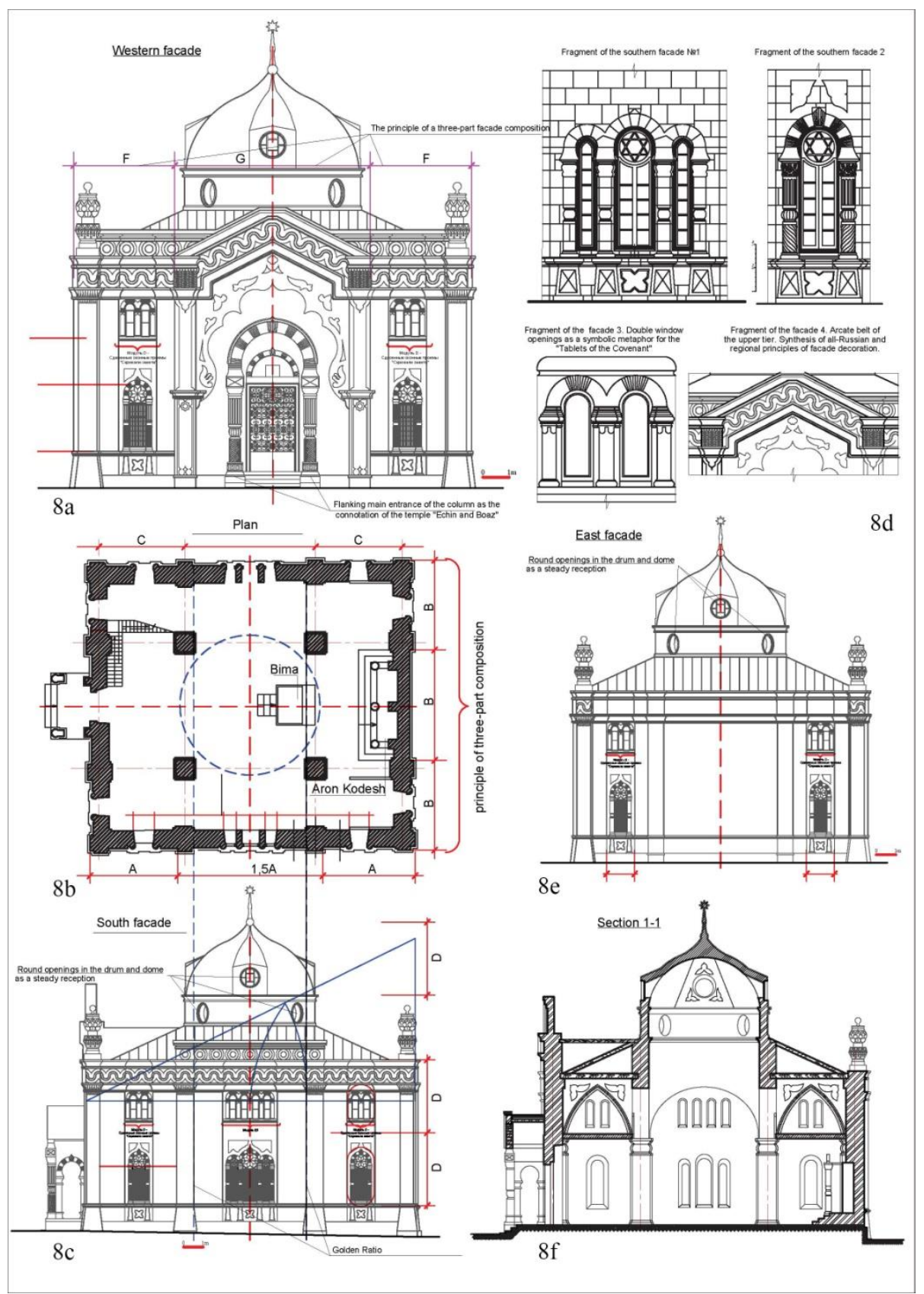

Figure 8 Synagogue in Oni.

8.a. Western facade. 8.b. Plan. 8.c. South facade. 8.d. Fragments. 8.e. East facade. 8.f. Section 1-1.

Thus, in the context of all-European trends of romantic historicism spread, neo-Moorish style had a well-established position of Jewish identity penetrating into the Don and the Caucasus regions through the dissemination of trends in prototyping and borrowing.

The principles of rationalism are the expression of the logical construction of internal space in external forms. The use of open brick aesthetics becomes a characteristic feature of the synagogue architecture of Tiflis and Kutaisi provinces of the early 20 century. Prayer halls had elongated and wide window openings in two lights, stairwells and lobbies were also decorated with vertical glazing. Modularity in construction of window openings of secondary rooms is defined. Minimization of decor, geometry and simplicity of forms create the general impression of asceticism of the synagogues architectural image in the region. 
The synagogue in Tumanyan Street was built in 1913 in a brick style and has a three-part facade with attic and side risalits. A large round window opening of the eastern facade which is peculiar to a modern architecture identifies the position of Torah ark in the prayer hall. The building stands on a complex relief which determines the variable number of storeys of the building.

The decorative ensemble of the facade is formed by brick archivolts of pointed-arched shape above the window and doorways and profiled framing of the round window opening.

The synagogue located in Catholicos Street built in 1918 in brick style and aesthetics is similar to the surrounding ordinary buildings of the same period. However, the composition dominant is a wide dome on a low drum dome with round windows and high window openings identify the functional purpose of the building. "All-facade" and asymmetries in the dimensional composition of the facades is peculiar to synagogues.

Thus, the dynamics of the synagogue architecture is manifested in a wide variability of combinations of typological features due to different ethno-linguistic composition of communities, socio-political and economic conditions, as well as sources of influence.

\section{CONCLUSION}

Summing up, it can be argued that the article contains a comprehensive analysis of the architecture of synagogues in the south of the Russian Empire. It was revealed that the architecture of synagogues was formed according to the principle of "dualism": on the one hand, stable principles of the formation of a planning structure are manifested, on the other, a wide palette of images and compositional solutions formed according to the principle of prototyping. This paradox makes synagogue buildings unique in a sense.

\section{AUTHORS' CONTRIBUTIONS}

Shapiro G.E. carried out comprehensive scientific research and collection of archival material.

Ivanova-Ilyicheva A.M. carried out bibliographic research, survey of objects, carried out scientific supervision.
Buchka A.M. was engaged in the preparation of graphic material and research in the field of stylistic directions of synagogues

\section{REFERENCES}

[1] The State Archive of Rostov region. Fund P203 , register 1 , file 889 . "Inventory of the property of the synagogues and chapels of Rostov-on-Don", 1915. (Gosudarstvennyi arkhiv Rostovskoi oblasti. Fond P-203, opis' 1, delo 889. "Inventarizatsiia imushchestva sinagog i chasoven Rostova-na-Donu", 1915) [in Russian].

[2] The State Archive of Rostov region. Fund 52, register 2, file 2. "The materials of the Jewish community and praying", 1887. (Gosudarstvennyi arkhiv Rostovskoi oblasti. Fond 52, opis' 2, delo 2. " Materialy evreiskoi obshchiny i molitvy ", 1887) [in Russian].

[3] Yu.S. Yankovskaya, Image and morphology of the architectural building. Abstract of the dissertation of the Doctor of Architecture (Obraz i morfologiia arkhitekturnogo ob"ekta. Avtoreferat dissertatsii doktora arkhitektury). Moscow, 2004 [in Russian].

[4] V. Levin, The St. Petersburg Jewish Community and the Capital of the Russian Empire: an Architectural Dialogue, in: Aliza Cohen-Mushlin and Harmen H. Thies (eds.), Jewish architecture in Europe. Petersberg: Michael Imhof Verlag, 2010, pp.189-192.

[5] Klein R., Oriental-Style Synagogues in Austria-Hungary: Philosophy and Historical Significance, in: Ars Judaica: The Bar-Ilan Journal of Jewish Art, no. 2, 2016, pp. 117134.

[6] Beizer M., Our Legacy: The CIS Synagogues, Past and Present. Jerusalem: Gesharim Moscow: Bridges of Culture. 